\title{
ZOE BENNETT
}

\section{PUSHING 'PAUSE' ON VIDEO EVIDENCE:}

An analysis of the proposed amendments

to $s \mathbf{1 0 6}$ of the Evidence Act 2006

\author{
Submitted for the LLB (Honours) Degree
}

Faculty of Law

Victoria University of Wellington

2014 


\section{Contents}

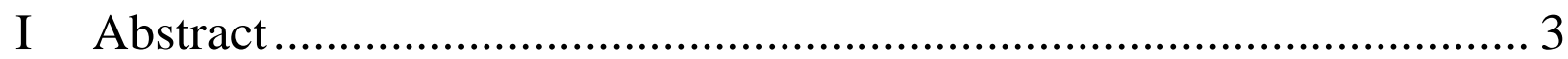

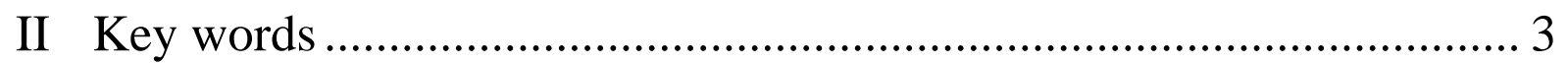

III Introduction: The method of disclosure of video evidence................. 4

IV The nature and form of video evidence.......................................... 6

A Prior to s 106 being engaged....................................................... 8

B The current operation of $s$ 106...................................................... 10

V Cabinets reaction: Amendments to the Evidence Act 2006 ............... 12

C Relevant case law ....................................................................... 13

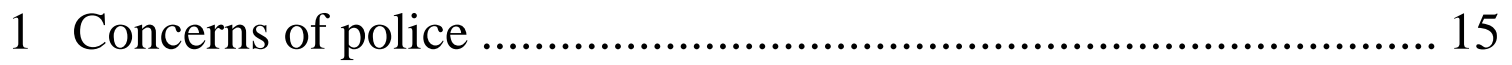

VI The proposed reforms: Are they the correct response? ..................... 17

D Doctrinal considerations: New Zealand Bill of Rights Act 1990..... 17

E Balancing the Rights of the Victim with the Rights of the Defence... 25

F Workability of amendments: do they address the current problem? 26

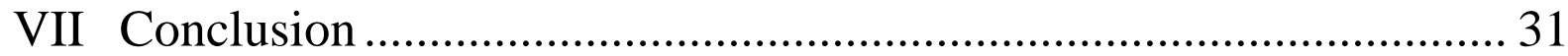

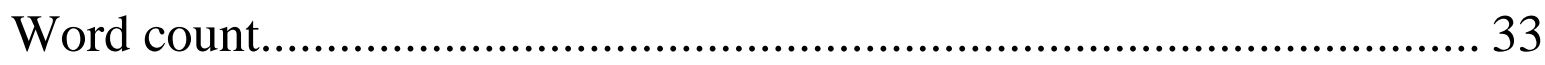

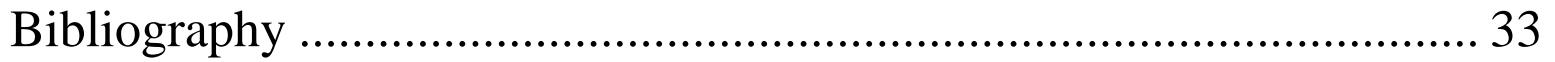




\section{Abstract}

This paper assesses the ramifications of the Cabinet Social Policy Committees proposals contained in the paper Amendments to the Evidence Act 2006. The Committee proposed a change to s 106 of the Evidence Act, which currently lies in favour of full disclosure of video evidence to the defence. The proposed amendments will reverse this presumption, ultimately restricting the defence's access to the complainants video evidence. This paper will assess the validity and practicality of these proposed amendments, by assessing whether they are consistent with the New Zealand Bill of Rights Act, the equality of arms doctrine and international case law. Although the proposed amendments were made to protect vulnerable complainants, attrition rates in New Zealand show that vulnerable witnesses do not drop out of the criminal justice system just because they are fearful about their video evidence being disclosed. The attrition rates are more complex. However, this paper argues that there are still adequate safeguards in place to protect the defence's right to a fair trial. Whilst these safeguards holdfast, any effort to protect vulnerable victims should be encouraged.

\section{Key words}

Evidence Act 2006

Video Evidence

Vulnerable Witnesses

Defence Rights

Fair Trial 


\section{Introduction: The method of disclosure of video evidence.}

Video record evidence is allowed to children and vulnerable adults who wish to give their evidence in chief at trial. Section 106 of the Evidence Act 2006 allows for vulnerable witnesses to give their evidence via video record, by recording the witness's forensic interview. ${ }^{1}$ Under s 106(4) of the Evidence Act 2006, all video record evidence that is to be offered in court as an alternative form of evidence must be disclosed to the defence lawyer before being offered as evidence. ${ }^{2}$ This provision has captured the attention of the Cabinet Social Policy Committee who, in 2013, proposed a change in the method of disclosure regarding video evidence. ${ }^{3}$ Currently, there is a presumption in favour of disclosure of the video evidence to the defence. Section 106(3) supports this presumption by stating:

A video record that is to be offered as an alternative way of giving evidence in a proceeding must be offered for viewing by all parties or their lawyers before it is offered in evidence, unless the Judge directs otherwise. $^{4}$

The Cabinet Social Policy Committee propose to reverse the presumption. The proposals aim to restrict defence access to the video evidence of a complainant, who has been a victim of sexual or serious offending, by only providing defence counsel with a transcript of the interview. If the defence wish to access the video evidence physically, then under the proposed changes, they will have to view it on

\footnotetext{
${ }^{1}$ Evidence Act 2006, s 106.

${ }^{2}$ At s 106(4)(a).

${ }^{3}$ Cabinet Social Policy Committee “Amendments to the Evidence Act 2006” (12 November 2013) at [50].

${ }^{4}$ Section 106(3).
} 
police premises (or at another premises agreed to by the parties) or apply to the court for the release of a copy, under the proposed changes. ${ }^{5}$

This paper will assess the possible effects of the proposed changes to s 106, examining both the positive and negative ramifications for vulnerable victims. Ultimately, this paper argues in favour of the proposed amendments. Although the defence's access to video evidence would be restricted, safeguards exist to protect the fair trial process. The defence can still view the video evidence on police premises, and can apply to the judge for a copy. Imaginably, the judge would allow the defence a copy of the complainant's video evidence in the appropriate circumstances; perhaps when it would threaten the defence's right to a fair trial.

This paper also evaluates the effectiveness of the proposed amendments. Attrition rates show that vulnerable complainants drop out of the criminal justice system for a number of reasons, proving that this is a wider problem. Not all witnesses who drop out do so because they are concerned with their video evidence being in the hands of the defence.

Nonetheless, the marginal difference these proposals could make outweigh the detriment to the defence. The amount of vulnerable witnesses the proposed amendments catch may be less than what Cabinet hoped for, but it is a reform that needs to happen. Additionally, the amendments do not necessarily take rights away from the defendants, because they still have reasonable access to the complainant's video evidence.

${ }^{5}$ Cabinet Social Policy Committee “Amendments to the Evidence Act 2006” (12 November 2013) at [50]. 
Before assessing the implications of the proposed reforms offered by Cabinet, the current operation of s 106 will be discussed, along with what is required to trigger s 106. The case of $R \vee$ Henning $^{6}$ discusses the functions of $\mathrm{s} 106$ and simultaneously presents the police's viewpoint regarding the operation of s 106, particularly their skepticism on video evidence being accessed by the defence. Henning is the most well-known case concerning video evidence and s 106, and has acted as a catalyst for statutory reform. ${ }^{7}$ Doctrinal issues also arise upon consideration of the New Zealand Bill of Rights Act 1990, the principle of a fair trial and the principle of equality of arms. Prima facie, Cabinet's proposed amendments to restrict the defences access to video records conflict with these doctrines. But upon closer analysis, the notion of a fair trial and equality of arms are subject to change, and are flexible in nature. Therefore, they are subject to a factual analysis, which ultimately decides what a fair trial is. Additionally, the Canadian case of $R v O^{\prime}$ Connor $^{8}$ offers a point of comparison to the New Zealand system, whilst analyzing the practicalities of the amendments helps identify the misconceptions of Cabinet in drafting the proposed amendments.

\section{The nature and form of video evidence}

Pre-recording video evidence is a method of information gathering used to preserve information given by complainants, and simultaneously protect them from the harsh reality of the adversarial system. Video evidence is able to capture

\footnotetext{
${ }^{6} R$ v Henning, DC Wellington CRI-2010-078-1159, 5 July 2011.

${ }^{7}$ Yvette Tinsley and Elisabeth McDonald "Evidence Issues” in Yvette Tinsley and Elisabeth McDonald (eds) From “Real Rape” to Real Justice: Prosecuting Rape in New Zealand (Victoria University Press, Wellington, 2011$) 123$.

${ }^{8}$ R. v. O'Connor [1995] 4 S.C.R. 411.
} 
the complainant's entire evidence, which arguably improves the likelihood of a just outcome by giving the police, and later the jury, a broader picture of the case. ${ }^{9}$

Recording the complainant's initial interview with the police allows the police to exercise the cognitive interviewing technique. This technique encourages police to 'sit back' and allow the complainant to report everything they remember about the event, including the surrounding circumstances and how they felt at the time. ${ }^{10}$ Research regarding the techniques effectiveness have been positive, with one study reporting that the cognitive interviewing technique increased the recall of information by $30-35 \%$ for adult witnesses. ${ }^{11}$

The Court of Appeal held in $M v R^{12}$ that in exceptional cases, the court has the jurisdiction to make an order for the pre-trial recording of cross-examination. In exercising this power, the court must carefully balance the benefits to the witness against the disadvantages to the defendant. ${ }^{13}$ The Court listed numerous reasons why, in non-compelling cases, the disadvantages outweigh the benefits. Complainants could end up giving evidence twice if new issues arose during trial, which frustrates the purpose of reducing the witnesses time in the criminal justice system. Ordering a pre-trial recording of cross-examination was seen to limit the jury's ability to assess the defendant's credibility and to see the defendant's reaction to evidence. The court was also concerned about the defendant not hearing the prosecutions opening before cross-examination. Generally, the

\footnotetext{
${ }^{9}$ Nina Westera, Mark Kebbell and Becky Milne "Losing two thirds of the story: A comparison of the video recorded police interview and live evidence of rape complainants” (2013) 4 Criminal Law Review 290.

${ }^{10}$ Mary Schollum “Investigative interviewing: The Literature” (2005) New Zealand Police, Wellington.

${ }^{11}$ Mark Kebbell, Becky Milne, and Graham Wagstaff “The cognitive interview: a survey of its forensic effectiveness” (1999) 5 Psychology, Crime and Law 101.

${ }^{12} M v R$ [2011] NZCA 303.

13 At 12.
} 
defendant is entitled to hear the charges against them. ${ }^{14}$ Finally, parties would have to pay more for legal services, as counsel for both parties would have to prepare for the pre-recording of the evidence as well as the actual trial. ${ }^{15}$

Despite challenges from the defence bar, many benefits are reaped from prerecording all or a portion of the complainant's evidence. Although this piece is primarily concerned with the complainant's evidential interview that is recorded initially by police, the overall concerns and effects of pre-recording video evidence remain relevant. Pre-recording evidence is a valuable, and somewhat dangerous tool. It can preserve evidence, speed up the complainant's time in the criminal justice system, and protect vulnerable complainants from the harsh reality of the courtroom.

\section{A Prior to s 106 being engaged}

Before s 106(4) is activated, s 103 of the Evidence Act regulates the use of alternative ways for witnesses to give evidence in criminal proceedings. Judges can direct a witness to give evidence in a certain way, such as pre-recording an evidential interview for evidence in chief, as provided in s 105 . What activates s 103 is the presence of vulnerability, youth, maturity (or lack of), fear, or a close relationship between the complainant and the defendant. ${ }^{16}$ Additionally, the judge must consider the fairness of the proceedings, and the potential impact, it could have on the witness, if an alternative form of evidence giving were to be

\footnotetext{
${ }^{14} M v R$, above n 12.

${ }^{15} M v R$, above $\mathrm{n} 12$.

${ }^{16}$ Evidence Act 2006, s 106.
} 
allowed. ${ }^{17}$ Since 2006, adult complainants have been recognized as a class of persons who need more access to other forms of evidence giving, in a greater drive to minimize stress and to assist a speedy recovery. ${ }^{18}$

There is no standard of proof threshold in ordering an alternative form of evidence giving within the Evidence Act, nor is there a presumption favouring 'normal' forms of evidence giving within the courtroom. As stated in $R v O$, the Court of Appeal held that s 103 allows the court a "broad and unfettered discretion"19 when making an order for an alternative form of evidence. The court asserted that there is no default position or presumption leaning in favour of giving evidence the ordinary way, as the court has the flexibility to consider the case at hand, and are not limited to cases involving "young and mentally impaired complainants in sexual cases.”20

Therefore the facts of each case must be considered before an order allowing an alternative form of evidence giving will be given. In deciding which route to take, the court must determine whether it would be fair to the proceedings. ${ }^{21}$ It is then up to the judge to decide whether to order the pre-recorded evidential interview to be used as evidence in chief.

\footnotetext{
${ }^{17}$ Section 103(4)(a)-(c).

${ }^{18}$ Tinsley and McDonald, above $\mathrm{n} 7$.

${ }^{19} R \vee O$ [2012] NZCA 475 at [37].

${ }^{20}$ At [37].

${ }^{21} R$ v Shone [2008] NZCA 313 at [28].
} 


\section{B The current operation of $s$ 106}

Section 106 of the Evidence Act 2006 deals specifically with the use of video evidence. If an evidential interview video record is to be offered as evidence in chief at the trial, s 106(4)(a) states the following:

A copy of any video record that is to be offered as an alternative method of giving evidence in a proceeding-

(a) must be given to the lawyer for each party before it is offered in evidence, unless the Judge directs otherwise; and

(b) must be dealt with in accordance with any requirements set out in regulations made under s 201 concerning the custody or return of copies of video records, or prohibiting or restricting their copying. ${ }^{22}$

In regulating the disclosure of video evidence to the defence, s 106(3) provides that if video evidence is to be used in court proceedings, then it must be offered to all parties and their lawyers, "unless the Judge directs otherwise."23 The Law Society were concerned about this section during the 2005 reforms of the Evidence Bill, claiming that the privacy of the complainant was sufficiently protected by statutory regulations and the ethical stature of counsel. ${ }^{24}$ The Select Committee agreed that the Law Society does have a degree of responsibility to “maintain adequate standards for lawyers,” but they were aware of the potential breach of privacy on behalf of the complainant if the video evidence was misplaced. Due to this concern, the Select Committee recommended that strict regulations be created and enforced, to protect the complainant's privacy and to

\footnotetext{
${ }^{22}$ Section 106(4)(a).

${ }^{23}$ Section 106(3).

${ }^{24}$ Justice and Electoral Committee Evidence Bill (256-2) (24 October 2006) at 12.
} 
create a structure that "governs the copying, custody and return of copies of video records." 25 These concerns have manifested themselves in s 201 of the Evidence Act 2006, and in the Evidence Regulations, 2007.

Section 201 regulates the use of the video evidence, asking for the consent of the person who is being filmed, and prescribing the purpose for which the video is being used. ${ }^{26}$ Under the Criminal Disclosure Act 2008, the prosecutor must disclose all relevant information to the defendant as soon as "reasonably practicable.”27 Section 29-34 of the Evidence Regulations 2007 specifically deals with the lawyer's copy of the video evidence. Under s 30 of the Regulations, police make a copy of their video evidence and supply it to the defendant's lawyer. ${ }^{28}$ Section 31 provides that the lawyer must keep the video evidence in "safe custody" and must return it to police "as soon as practicable after the criminal proceeding. ${ }^{29}$ A lawyer cannot make a copy of the video evidence, ${ }^{30}$ and they can only use the video evidence when preparing their defendants criminal case. ${ }^{31}$ The protections encased in the Evidence Regulations and the Criminal Disclosure Act consequently serve to protect the complainant's video evidence from being used inappropriately, or being broadcast to a wider class of persons.

In 2010, the Law Society also expressed concerns about the workability of s 106(4), claiming that police practice differed from the practice stipulated by $\mathrm{s}$ 106(4)(a) of the Act. The Law Society reported that the police don't always comply with s 106(4)(a), and deny copies of child complainant recordings to

\footnotetext{
${ }^{25}$ At 12.

${ }^{26}$ Section 201.

${ }^{27}$ Criminal Disclosure Act 2008, s 13.

${ }^{28}$ Evidence Regulations 2007, reg 30.

${ }^{29}$ Reg 31.

${ }^{30} \operatorname{Reg} 32$.

${ }^{31}$ Reg 32.
} 
defence counsel. ${ }^{32}$ The Law Commission responded by stating that they needed "further information" about the difficulties police were creating, to consider making changes to the regulations, to allow counsel for the defendant a copy of the recorded evidence. ${ }^{33}$

\section{Cabinets reaction: Amendments to the Evidence Act 2006}

Despite safeguards provided by the Criminal Disclosure Act and Evidence Regulations, the Cabinet Social Policy Committee issued the paper Amendments to the Evidence Act 2006 in November 2013. The suggested amendments presented by the Committee proposed restricting the defence's access to the video records of complainants whose evidence is of a "sexual or violent nature, and of child victims' evidence in all cases.” Therefore the evidence gathered during the initial interview with the police would not automatically find its way into the defence's hands. Instead, the defence would get a transcript. If the defence wanted to view the video evidence, they would have to do so on police property, or at another place agreed upon by the parties. Alternatively, the defence could apply to the court for a copy if none of the above arrangements suited. ${ }^{34}$

In addition, the Committee sought to make regulations prescribing offences for non-compliance, with a special emphasis on governing the safety of the video record. The maximum fine would be up to " $\$ 2,000$ for an individual or up to \$10,000 for an organisation.”35 The following would be an offence:

\footnotetext{
${ }^{32}$ Richard Mahoney and others The Evidence Act 2006: Act and Analysis (2nd ed, Brookers, Wellington, 2010).

${ }^{33}$ Mahoney and others, above $\mathrm{n} 32$.

${ }^{34}$ Cabinet Social Policy Committee “Amendments to the Evidence Act 2006” (12 November 2013) at [50].

${ }^{35}$ At [51].
} 
- Copy, distribute or exhibit a copy of the video record without authorisation, with a maximum penalty of a term of imprisonment not exceeding six months or a fine of $\$ 10,000$ for an organisation;

- Possess a video record without authorisation, having an intention to copy, distribute or exhibit the video record; with a maximum penalty of a term of imprisonment not exceeding six months or a fine of $\$ 10,000$ for an organisation;

- Possess a copy of a video record without authorisation with a maximum penalty of a fine up to $\$ 2,000$ for an individual and up to $\$ 10,000$ for an organisation. ${ }^{36}$

The Committee was particularly concerned about the risk of video records being exposed to the public or unauthorised persons. This risk was heightened by the videos being of vulnerable witnesses, which had the potential to fall into "the wrong hands" and be used for inappropriate purposes. ${ }^{37}$ A transcript of the interview was deemed to be sufficient for the purposes of the defence, thus decreasing the risk of sensitive information about the complainant and their case being misused.

\section{Relevant case law}

The District Court case of $R v$ Henning ${ }^{38}$ was a catalyst for reform and is the most well-known of its kind. ${ }^{39}$ The discussion around s 106 in Henning showcased the concerns of police, and reflect the concerns of the Cabinet Social Policy Committee. Both organisations were concerned about protecting vulnerable

\footnotetext{
${ }^{36}$ Cabinet Social Policy Committee “Amendments to the Evidence Act 2006” (12 November 2013) at [52].

${ }^{37}$ At [48].

${ }^{38} R$ v Henning, DC Wellington CRI-2010-078-1159, 5 July 2011.

39 Tinsley and McDonald, above n 7.
} 
witnesses. Ultimately, in Henning the judge had to consider the functionality of s 106 if he were to rule in favour of the complainant. The complainant was 18, but at the time of the alleged offence, he was 17. For the purposes of the Evidence Act, he was a child. Thus s 107(1) was activated, and the Crown had to apply to the Court for direction about how the complainant would give evidence in chief and be cross-examined. ${ }^{40}$ The Crown sought to use the complainant's recorded evidential interview for his evidence in chief, but the defence refused to comment "until the recording is seen by the defence."41 The suggestion of viewing the video at a police station or Crown office was rejected.

Consequently, the Crown sought direction from the court under s 106(4)(a). In situations where disclosure was not "in the interests of justice” the Crown argued that the Court has the power to restrict the defendant's access to the video evidence, under s 106(4)(a). ${ }^{42}$ It was further argued that the Evidence Regulations 2007 could not fully guarantee the complainant's safety or anonymity, especially with the abundance of technology that allows easy distribution of such material. ${ }^{43}$ Ultimately, it was argued that a copy of the transcript of the video evidence was sufficient for the defendant's purposes. In the alternative, the Crown noted that it was not unheard of for defence counsel to view the video evidence at the Crown Solicitors office, or at a police station. ${ }^{44}$

\footnotetext{
${ }^{40}$ At [1].

${ }^{41}$ At [2].

${ }^{42}$ At [9].

${ }^{43}$ At [10].

${ }^{44}$ At [22].
} 


\section{Concerns of police}

Nonetheless, two affidavits were entered by members of the police force, which reflect the concerns of the Cabinet Social Policy Committee. Detective Inspector Nina Westera was one of the police officers who entered an affidavit detailing the use of video evidence. ${ }^{45}$ Westera noted that prior to the Evidence Act 2006 being passed into law, the defence was only provided with a transcript of video evidence and could only view the video with their client under police direction. She claimed that since the Evidence Act, "there have been several instances involving potential misuse of such sensitive material." 46 Westera even noted that on one occasion, a defence lawyer lost their copy of the evidential interview containing reported violations of a sexual nature by a 9-year old complainant. ${ }^{47}$ Furthermore, the danger of providing video evidence to the defendant could undo the police's hard work convincing victim support groups to support the use of video evidence. As Westera argues, all it would take to undo the agencies support for video evidence would be for one illegal release, perhaps on the internet. ${ }^{48}$

Detective Senior Sergeant Neil Holden was the second police officer to swear an affidavit. His evidence was particularly influential as he held the National CoOrdinator position of Adult Sexual Assault and Child Abuse. He was particularly concerned about the wider societal effect in allowing the defence access to the recorded video evidence. He claimed that there is a likelihood of re-victimisation if the defendant 'gets their hands on' the evidence, as they can use it as a weapon

${ }^{45}$ At [14].

${ }^{46}$ At [14].

${ }^{47}$ At [14].

${ }^{48}$ At [15]. 
in retaliation of being taken to court. ${ }^{49}$ Additionally, there was also the concern that vulnerable witnesses may not trust the criminal justice system to handle their case, and are therefore less likely to report it to the police if they know the defendant has access to their evidential interview later. $^{50}$

Despite the concerns voiced by the police, the judge in Henning held that if he were to agree with the Crown, he would essentially undermine the workability of s 106(4)(1). Considering the facts of the case, Mr Henning had no previous convictions and had interim name suppression. On this basis, Harrop $\mathrm{J}$ held that there was "considerably less reason in this case for the Court to be concerned about the risk of misuse than there may be in other cases."51 Because Mr Henning had name suppression, misusing the video evidence and releasing it into the public, thus identifying himself as a sexual offender, would be detrimental to himself. This, coupled with the strict obligations of his defence lawyer to protect the evidential interview, made the risk of misuse very slim..$^{52}$

The concerns raised by Detective Inspector Nina Westera and Detective Senior Sergeant Neil Holden compliment and expand upon the concerns of the Cabinet Social Policy Committee. All are concerned with the perceived risk of the evidential video record being misused, thus breaching the complainants privacy and increasing the risk that other victims would not consent to an evidential interview with police, or go to police at all. This is particularly relevant in an age

${ }^{49}$ At [18].

${ }^{50}$ At [19].

${ }^{51}$ At [28].

${ }^{52}$ At [26]. 
of accessible technology, where sensitive video information can be uploaded and downloaded with considerable ease off the internet. ${ }^{53}$

VI The proposed reforms: Are they the correct response?

Cabinets proposed changes to the Evidence Act were made in favour of vulnerable complainants, aiming to protect them while they are submitting sensitive information, and encouraging other victims of serious or sexual offences to report the crime to police. However this means that the defendant will not get immediate access to the footage. Mr Bott, for the defence in Henning, argued that they should have the right to take the video evidence away in order to build a proper defence. ${ }^{54}$ There are some doctrinal difficulties in restricting the defendant's access to evidence regarding the case against them, and those are briefly discussed next.

D Doctrinal considerations: New Zealand Bill of Rights Act 1990

The Cabinet Social Policy Committee concluded that there were no inconsistencies with the New Zealand Bill of Rights Act 1990 (BORA) because "the defence will be able to access a copy of the video when a court considers this to be necessary.”55

Section 25 of BORA states the minimum standards of criminal procedure:

${ }^{53}$ At [10].

${ }^{54} R v$ Henning, above $n 38$.

${ }^{55}$ Cabinet Social Policy Committee, above n 3, at [60]. 
Everyone who is charged with an offence has, in relation to the determination of the charge, the following minimum rights-

$[\ldots]$

(f) The right to examine the witnesses for the prosecution and to obtain the attendance and examination of witnesses for the defence under the same conditions as the prosecution. ${ }^{56}$

Section 25(f) is based on article 14.3 of the International Covenant on Civil and Political Rights (ICCPR), which states:

In the determination of any criminal charge against him, everyone shall be entitled to the following minimum guarantees, in full equality:

(a) To be informed promptly and in detail in a language in which he understands of the nature and cause of the charge against him;

(b) To have adequate time and facilities for the preparation of his defence and to communicate with counsel of his own choosing

$[\ldots]$

(e) To examine, or have examined, the witnesses against him and to obtain the attendance and examination of witnesses on his behalf under the same conditions as witnesses against him... ${ }^{57}$

Article 6(3)(b) and (d) of the European Convention of Human Rights (ECHR) echoes these principles, emphasizing the importance of allowing the defence sufficient and proper facilities to prepare a defence. ${ }^{58}$ This idea is also

\footnotetext{
${ }^{56}$ New Zealand Bill of Rights Act 1990, s 25(f).

${ }^{57}$ International Covenant on Civil and Political Rights, art 14.3.

${ }^{58}$ Council of Europe Convention for the Protection of Human Rights and Fundamental Freedoms as amended by Protocols No. 11 and No. 144 November 1950, ETS 5.
} 
characterised as the jurisprudential principle of equality of arms, which originated in the European Court of Human Rights and is regulated by article 6 of the ECHR. ${ }^{59}$ The doctrine stipulates that both parties should have an equal opportunity to present their case in court, thereby discouraging any non-equal treatment between parties. An example of non-equal treatment would therefore be "sending only to the prosecutor and not also to the defence the police reports." 60

The equality of arms doctrine has close ties to the notion of a fair trial. In New Zealand, Section 25 of BORA reflects the common law concept of a fair trial. It attempts no precise definition of a fair trial, and whether one has taken place is dependent on a factual inquiry. ${ }^{61}$ However, the overarching principle of fairness can be applied to the initial mechanisms of a trial, such as the giving and taking of evidence, as it contributes to the 'quality' of the trial process. It is the 'quality' of the trial that determines whether it is fair. ${ }^{62}$ Whereas for the notion of equality of arms, the European doctrine calls for adequate and fair procedural standards for both parties. The general principle is that parties disclose documents that they will use in court, as well as documents that may be detrimental to their case. ${ }^{63}$ Both parties should also exchange statements of the witnesses that they will call in trial in advance. ${ }^{64}$ On this basis, it appears that restricting the defendant's access to the evidential interview of the complainant violates this European convention. The proposed amendments would not put both parties on an equal footing, as the prosecution does not declare the evidential interview to the defendant. The

\footnotetext{
${ }^{59}$ Council of Europe, above n 58.

${ }^{60}$ Elisa Toma “The Principle of Equality of Arms- Part of the Right to a Fair Trial” (2011) 1(3) Romania Law Review 1.

${ }^{61}$ Ministry of Justice The Guidelines on the New Zealand Bill of Rights Act 1990: A Guide to the Rights and Freedoms in the Bill of Rights Act for the Public Sector (Ministry of Justice, November 2004).

${ }^{62}$ Ministry of Justice, above $n 61$.

${ }^{63}$ Human Rights Review “Article 6: the Right to a Fair Trial” (2012)

$<$ http://www.equalityhumanrights.com/uploaded_files/humanrights/hrr_article_6.pdf>.

${ }^{64}$ Human Rights Review, above n 63.
} 
defence would have to work harder to overcome the non-equal treatment, and would only be able to view the video on police premises, without an order from the judge.

However, there has been some uncertainty over this principle of equality of arms and whether it is protected in either s 24 or s 25 of BORA. In $R v$ Heemi, Chief Justice Eichelbaum held that it was not necessary to find an answer regarding the admissibility of the doctrine into BORA. ${ }^{65}$ Despite this, the doctrine is still applicable, because it allows for a balancing exercise; recognising that the concept of a fair trial is not rigid and absolute. This was highlighted in the case Fitt $v$ United Kingdom, ${ }^{66}$ where the European Court of Human Rights held that the defendant's right to be disclosed all relevant material of the prosecution's case was not absolute. They recognized that in circumstances of competing interests, such as national security or the need to protect witnesses or police investigative methods, the complainant's interests would be weighed against the defence's interests. ${ }^{67}$

The Canadian case $R v O^{\prime}$ Connor ${ }^{68}$ also discusses the balance between a fair trial and the victim's right to privacy and confidentiality. In this case, the defendant was accused of multiple sexual offences. The issue was whether the Crown could disclose the complainant's medical, counselling and school records. In making this decision, the Supreme Court of Canada discussed the balance between the privacy and rights of the complainant, and the defendant's right to a fair trial. ${ }^{69}$

\footnotetext{
${ }^{65} \mathrm{R}$ v Heemi CA143/98, 5 October 1998.

${ }^{66}$ Fitt $v$ UK (2000) 30 EHRR 480.

${ }^{67}$ At [45].

${ }^{68}$ R. v $\mathrm{O}^{\prime}$ Connor, above n 8.

${ }^{69}$ At [32].
} 
The majority in O'Connor held that a balancing exercise must be undertaken before an order for disclosure is made. This is because there is an assumption that disclosure of sensitive information to the defendant will not infringe upon the privacy of the complainant, because the judge will limit accessibility to the public. $^{70}$ Therefore, the sensitive information is restricted initially for the defendant. Under this model, the balancing exercise occurs later. ${ }^{71}$ This balancing exercise occurs later, if the defence applies to the judge for a copy of the sensitive information. Only then will the rights of the complainant be balanced against the defence's right to access all information easily for the sake of their case. The judge considered whether the record was necessary for the accused to make full answer and defence, alongside the nature and extent of the reasonable expectation of privacy and the extent to which production of records of this nature would frustrate society's interest in encouraging the reporting of sexual offences and the acquisition of treatment by victims. ${ }^{72}$

O'Connor gives a more detailed account of what a judge should consider when evaluating whether to disclose sensitive information to the defence. Under the proposed amendments to s 106, no such analysis is undertaken. Rather, the defendant is automatically restricted from obtaining the sensitive video information. Although the judge can decide later whether to make an order in favour of the defendant, and allow the evidential interview into the possession of the defendant, the balancing process as described in O'Connor between the interests of the complainants privacy and the interests of the defence is not conducted until later. Therefore the amendments to s 106 fall in favour of the complainant first, until the defendant challenges it.

\footnotetext{
${ }^{70}$ At [32].

${ }^{71}$ At [32].

${ }^{72}$ At [156].
} 
In New Zealand, the case Attorney-General v Otahuhu District Council assessed whether O'Connor was persuasive in New Zealand. The Court held that it was not necessary to make a decision on whether the rights under New Zealand BORA should prevail over the common law doctrine of abuse of process, but believed that in the future, the rights exercised under BORA would be exclusively relied upon. ${ }^{73}$ The Court also reiterated that $O^{\prime}$ Connor held that the "mere failure to disclose material will not necessarily amount to a violation of the Charter right to make full answer and defence."74 Although O'Connor dealt with sensitive information in the hands of third parties, the Court in Otahuhu District Council noted that the minority in $O^{\prime}$ Connor expanded this to sensitive information held by the Crown. Therefore, the criteria given by the majority regarding evidence held by third parties, can also be applied to Crown entities. The minority's reasoning stipulated that not all Crown actions are justified, therefore the same criteria could be applied to the Crown. ${ }^{75}$

Although the decision of O'Connor deals with sensitive information in the hands of third parties, the Canadian approach endorses a balancing exercise. In New Zealand, under the notion of a fair trial, a similar balancing exercise is conducted. The right to a fair hearing has been described as "the ultimate right from which all procedural rights could be deduced...Fairness in the criminal system is an imperative."76 There is no doubt that the right to a fair trial is a protected right in New Zealand society, but the extent of such protection is debatable, especially

\footnotetext{
${ }^{73}$ Attorney-General v Otahuhu District Court \& Anor [2001] 1 NZLR 737 at [52].

${ }^{74}$ At [53].

${ }^{75}$ At [55].

${ }^{76}$ Paul Rishworth and others The New Zealand Bill of Rights (Oxford University Press, Auckland, 2003).
} 
when the idea of fairness must apply to both parties. ${ }^{77}$ Fairness is not an all enveloping concept for both parties: "fairness to the prosecution is not the same as fairness to prosecution witnesses."78 From this perspective, it is difficult to see what a fair trial looks like, even though it is guaranteed under New Zealand BORA. The concept of a fair trial is not absolute, according to the Ministry of Justice, as it depends on the facts of the case. Furthermore, there is the proposition that the right to a fair trial is a limited right that changes with each case, to take into account the other parties rights and values, so that the accused "may have to accept something less than fairness." ${ }^{79}$ In Gisborne Herald Co Ltd v SolicitorGeneral $^{80}$ the Court of Appeal held that s 5 of BORA identifies the limits on the rights and freedoms contained in BORA, and that a balancing process needs to be undertaken by the Court to assess society's values. As Richardson J stated, the right to a fair trial can be limited, justifiably, by other values. ${ }^{81}$

In the Court of Appeal case $R v$ Hines, ${ }^{82}$ Richardson $\mathrm{P}$ and Keith $\mathrm{J}$ refer to the ECHR and the ICCPR, stating that under the position of these international standards, the right of an accused to a fair trial is "subject to derogation." 83 The judges say that the fair trial provisions are not listed specifically in the nonderogable articles of the ECHR or the ICCPR. They believe that this suggests the right to a fair trial is not absolute, "but may be qualified in the exceptional circumstances of a public emergency if strictly required by the exigencies of the situation." ${ }^{84}$ Although an obiter point, this dicta shows that the notion of a fair trial is not to be used absolutely in every case. Situations may arise where it is just

\footnotetext{
${ }^{77}$ Rishworth and others, above $\mathrm{n} 76$.

${ }^{78}$ Don Mathias “The Accused’s Right to a Fair Trial: Absolute or Limitable?” (2005) 2 NZLR 217 at 217.

${ }^{79}$ Mathias, above n 78, at 218.

${ }^{80}$ Gisborne Herald Co Ltd v Solicitor-General [1995] 3 NZLR 563, 573.

${ }^{81}$ At 573.

${ }^{82} R v$ Hines (1997) 3 NZLR 529, 548 (CA).

${ }^{83}$ Mathias, above $n$ 78, at 223.

${ }^{84} R v$ Hines, above $n 82$.
} 
and fair to bend the concept and allow less fairness to the defence for the sake of the complainant.

Amongst this dicta, there is room within s 24(d) and s 25(f) of BORA to allow for the proposed changes to s 106 of the Evidence Act. Under the proposed changes, the presumption of disclosure favouring the defence will be reversed. However, the trial will still remain fair to the accused, as a balancing mechanism is invoked: the rights of the defence and the rights of the vulnerable complainant are balanced. Even though the doctrine of equality of arms has not been incorporated into BORA, it too supports the contention that the right to a fair trial is not a rigid, absolute concept.

In the case of a vulnerable complainant, the public interest arguably weighs in favour of restricting the defence's access to the evidential video evidence, as it may result in a miscarriage of justice. If the defendant were to misuse the video evidence, or to lose it, ${ }^{85}$ this would most certainly amount to a miscarriage of justice. In the case of Hines, New Zealand judges have compared the ECHR and the ICCPR to the New Zealand BORA, and determined that they are alike in the sense that they appear to have enough room to incorporate this balancing exercise. The existence of s 5 in BORA appears to allow a limitation of the right to a fair trial, by providing that the rights and freedoms encased in the legislation "may be subject only to such reasonable limits prescribed by law as can be demonstrably justified in a free and democratic society." ${ }^{86}$ It seems that there is a strong case in favour of vulnerable complainants, whose interests should be protected for the sake of preserving a free and democratic society, if the fairness of the trial for the

\footnotetext{
${ }^{85} \mathrm{R} v$ Henning, above $\mathrm{n} 38$.

${ }^{86}$ New Zealand Bill of Rights Act 1990, s 5.
} 
defendant is not severely affected. Ultimately, the defence always receives a transcript of the video interview, and can apply to the judge for a copy of the video evidence.

\section{$\boldsymbol{E} \quad$ Balancing the Rights of the Victim with the Rights of the Defence}

One of the main drivers for the Cabinet Social Policy Committee's amendments was to protect the privacy and interests of the vulnerable witnesses, who were either children or alleged victims of a sexual or violent attack. The fast advancement of technology and media distribution puts the video evidence of the complainant at an even greater risk of being used inappropriately.

The Ministry of Justice have recognised this issue and the potential impact the internet and other forms of media distribution technology can have on witnesses or victims. In a Regulatory Impact Statement entitled Harmful Digital Communications, the Ministry of Justice recognised that the internet provides a “unique forum” for harassment that is easy to create and distribute and is difficult to regulate. ${ }^{87}$ Therefore the effects of new communication technologies are more dangerous because they have the potential to be more intrusive, persuasive and can cause more harm than other, more traditional forms, of communication. ${ }^{88}$ Providing a copy of the evidential interview for the defendant to view on police premises only, or by order of a judge, would decrease the possibility of the video evidence being released online.

With this inherently more dangerous form of communication, the rights of the victim or witness must be carefully balanced against the defendant. As discussed

\footnotetext{
${ }^{87}$ Aphra Green Regulatory Impact Statement: Harmful Digital Communications (Ministry of Justice, 2013) at [11]. ${ }^{88}$ Green, above n 87.
} 
above, if s 25 of BORA is not met, there must be a sufficient reason in the name of fairness to let this breach occur. Protecting a vulnerable witness is recognised as a sufficient reason, but protecting victims rights should not encroach upon the defendants rights to a fair trial. In New Zealand, the Victims’ Rights Act 2002 regulates the treatment of victims, clarifying that a victim has the right of privacy, as stipulated by the Privacy Act $1993 .^{89}$ Victims can expect to be treated with “respect for your dignity and privacy and with courtesy and compassion.,"90

\section{F Workability of amendments: do they address the current problem?}

Under the proposed amendments, questions arise over the practical workability of the changes, and whether they 'live up' to expectations. One of the expectations emitting from Cabinet when proposing the amendments was to protect the vulnerable complainant and simultaneously encourage more victims of sexual and violent offences to report to police. However, it is questionable whether restricting the defence's access to the video evidence weighs substantially on the victims mind- so much so that it would deter them from reporting to the police. Therefore the key question is: are complainants really deterred by the prospect of their video evidence being viewed by the defendant? And furthermore, are they concerned about the video evidence reaching 'the wrong hands?'

The report commissioned by the Ministry of Women's Affairs Responding to sexual violence: Attrition in the New Zealand criminal justice system attempted to illuminate the issue of 'victim withdrawal' from the criminal justice system. The

\footnotetext{
${ }^{89}$ Victims’ Rights Act 2002, s 15.

${ }^{90}$ Ministry of Justice “A Guide to the Victims Charter” Ministry of Justice $<$ http://www.justice.govt.nz/publications/global-publications/v/victims-charter-booklet-a-guide-to-the-victimscharter/documents/23510-Victims-Booklet-13-0.pdf>
} 
report noted that victims withdrawing from the criminal justice procedure was a common event, especially when the alleged crime was one of sexual violence. ${ }^{91}$ At least one in five cases withdraw before reaching an end in court, with victims not wanting to proceed or not co-operating with the investigation. ${ }^{92} 30$ per cent of victims recorded in the report "could not be contacted, refused to give incident details or refused to make a formal complaint after the initial report."93 The remaining 70 per cent of cases were withdrawn at the victims request. For more than half of that 70 per cent, no reason was given for withdrawing. However, the remaining 139 cases gave an indication of what the police perceived to be the reason why the victim withdrew from the case. Amongst those reasons, the following were present:

- The victim felt afraid or threatened

- The victim felt like they couldn't face the process

- The victim was concerned about family reaction

- The victim wanted to move on. ${ }^{94}$

Due to the scope of the report, it was unclear whether the police investigation process played a role in the victim's decision to withdraw their case. The victim's reasons for withdrawing were broad, but mostly ranged between reluctance to go through the investigative or trial process, concern for others, fear of retribution or because they had elicited a negative response from police- either the police did not believe them, or the police had informed them about the low chance of

\footnotetext{
${ }^{91}$ Triggs and others Responding to sexual violence: Attrition in the New Zealand criminal justice system (Ministry of Women's Affairs, September 2009).

${ }^{92}$ Triggs and others, $\mathrm{n}$ 91, at 49.

${ }^{93}$ At 49 .

${ }^{94}$ At 50.
} 
conviction..$^{95}$ Withdrawn cases were "more likely than other cases to involve an offender who was an ex-partner or boyfriend." 96

The negative aspects of the trial from the victim's perspective has been well documented. So much so that judges and lawyers themselves sometimes advise victims against reporting sexual or serious offences, for the trauma of being a complainant is too great. ${ }^{97}$ Previous victims of sexual or violent offenses have detailed their participation in their own trial, labeling it "disgusting," “degrading” and likening it to "being forced to have sex in front of a whole lot of people."98 The low conviction rate for rape is also a large deterrent for victims to report the offence to police, or to continue with the court process. Although research shows that around 20 per cent of girls have experienced some form of sexual violence, ${ }^{99}$ only nine per cent of sexual offences are reported to the police. ${ }^{100}$

A less documented reason as to why victims are reluctant to report a sexual or violent offence to the police, is the possibility of video evidence landing in the hands of the defence, or other party. During an evidential interview with the police, which is usually involves matters of a sexual or violent nature, a large number of victims stated that they were wary of revictimisation, in the sense that their private evidence would be played in trial. ${ }^{101}$ When their evidence was displayed or questioned in court, some felt that they were being held liable for

\footnotetext{
95 At 50 .

${ }^{96}$ At 9.

${ }^{97}$ Elisabeth McDonald “Sexual Violence on Trial: Assisting Women Complainants in the Courtroom” (2005) 19(2) Women's Studies Journal, 2005, 107, at 113.

${ }^{98}$ Venezia King and Jan Jordan Responding to Sexual Violence: Pathways to Recovery (Ministry of Women's Affairs, Wellington, 2009) at 7.3.2.

${ }^{99}$ Ministry of Women’s Affairs “Dialogue on sexual violence” (1 May 2014) <http://mwa.govt.nz/news/dialoguesexual-violence>.

${ }^{100}$ Ministry of Women's Affairs Restoring Soul: Effective Intervention for Adult Victim/Survivors of Sexual Violence (Ministry of Women's Affairs, October 2009) at 1.3.

${ }^{101}$ Barbara Krahe and Jennifer Temkin Sexual Assault and the Justice Gap: A Question of Attitude (Hart Publishing, Oxford, 2008).
} 
what happened to them. ${ }^{102}$ In Australia, a victim's medical records, and even information about any counselling the complainant may have received, can be sought by the defence to undermine the credibility of complainants in sexual assault trials. ${ }^{103}$ It has been suggested that this knowledge causes a great deal of stress to the complainant or victim, and can lead to the complainant withdrawing their complaint. ${ }^{104}$ This discourse can be linked to the concerns of Cabinet regarding their proposed reforms, and to the concerns of Detective Senior Sergeant Neil Holden in Henning: that if complainants are concerned about their personal information being released to the defence and, in the worst case scenario, to the greater public, they are likely to refrain from reporting the offence, or are more likely to drop out of the criminal justice process altogether.

But this fear of the complainants- of their video evidence making its way into the hands of the defence- cannot be considered in isolation. There are multiple factors affecting the complainant's choice to report the sexual or violent offence to the police, not just the possibility of the video evidence being in the hands of the defence before the trial. For instance, complainants are more likely to be affected by the attitude of police toward their case, rather than their video evidence being presented to the defence. When the complainant first reports the offence, the initial contact with police is deemed the most crucial in deciding whether the victim wants to continue with their case or not. ${ }^{105}$ This stage of the investigative process is seen as a "critical determinant of whether complainants will be able to develop sufficient trust in the police to feel able to proceed with an

\footnotetext{
102 Krahe and Temkin, above n 101, at 41.

103 Jennifer Temkin “Digging the Dirt: Disclosure of Records in Sexual Assault Cases” (2002) 61(1) The Cambridge Law Journal 126.

104 Tinsley and McDonald, above $n 7$.

105 Jan Jordan “Worlds Apart? Women, Rape and the Police Reporting Process” (2001) 41(4) Br J Criminol 679 , at 688.
} 
investigation.”106 Therefore the attitude of police and how they interact with the complainant paints a bigger picture as to why victims 'drop out' of the criminal justice process. The complainant's view of the police, the attitude of police during the initial contact with the complainant, the reporting process, the medical examinations, the issue of disclosure- all can be reasons collectively or individually as to why complainants negate to report sexual or serious offences, or why they drop out of the criminal justice system prematurely. ${ }^{107}$ The issue of the video evidence being disclosed immediately and fully to the defence is therefore only one facet of a bigger problem.

Adopting the proposed amendments into the Evidence Act would also affect the defence's use of video evidence. As Mr Bott described in Henning, the defence's routine would be disrupted by the proposed amendments, as they would not be able to study the video evidence when it best suited them. Mr Bott said that he would rather study the evidential video interview in "his chambers and at time that suits him, which probably would be later in the evening after a busy day in Court." ${ }^{108}$ By amending the Evidence Act, a defence lawyer would have to visit police premises or Crown premises to view the evidential interview, or view it at another specified place. ${ }^{109} \mathrm{Mr}$ Bott submitted that this would be unreasonable to expect defence counsel to do this, especially when they would want to revisit evidence multiple times. ${ }^{110}$

Although the new amendments would restrict the ability of the defence to 'have the evidence in their hands,' the evidence is still accessible, albeit not on their

\footnotetext{
106 Jordan, above n 105, at 688.

107 Jordan, above n 105, at 688 .

${ }^{108} R$ v Henning, above $\mathrm{n} 38$, [23].

${ }^{109}$ Cabinet Social Policy Committee, above n 3.

${ }^{110} R$ v Henning, above $\mathrm{n} 38$, [23].
} 
terms. The weighing exercise as described in O'Connor, the New Zealand BORA literature, and the equality of arms doctrine weighs in favour of protecting the privacy and security of the vulnerable witnesses. The loss incurred to defendant does not equate to the potential loss to the complainant if their video evidence were to be misplaced. Already there have been cases of video evidence being misused, and lost. ${ }^{111}$ Therefore, the privacy of the victim outweighs the defence's concerns about not having a copy of the evidential interview 'in their hands,' as it is still generally accessible in order to construct a defence.

\section{Conclusion}

Although it is unclear whether the doctrine of equality of arms is facilitated under the New Zealand Bill of Rights Act, it sets out what is expected of parties regarding disclosure. The defence, under this doctrine, is entitled to full and timely disclosure of all material relevant to the case, to construct a fair and viable defence. However, this must be balanced against the vulnerable witnesses rights. This, in conjunction with the prevalence of new technology and the dangers associated with uploading and downloading media, concerned Cabinet and drove their proposed amendments.

Cabinet's proposals were created in good faith; their aim was to protect vulnerable witnesses from the harshness of the courtroom. Although the proposed amendments overlook other reasons why vulnerable witnesses are apprehensive of the criminal justice system, they seek to eliminate a small class of witnesses who drop out of the criminal justice system because they are afraid of their video

\footnotetext{
${ }^{111} R$ v Henning, above n 38, [14].
} 
evidence falling into the hands of the defence. However small this class may be, it still outweighs the detriment suffered by the defence, through restricting their access to the complainants video evidence. Three obvious safeguards would still exist to protect the defendant's right to a fair trial if these amendments were to be adopted. First, the defence would receive a full transcript of the video interview. A transcript contains the entire interview between the police and the complainant. Second, the defence can view the video evidence on police premises. Although this may interrupt the daily life of defence counsel, it is inaccurate to state that the defendant's rights have been extinguished by determining where the video evidence is to be viewed. Finally, the defence can still apply to the judge for a copy of the video evidence. In circumstances where limiting the defence's access to the video evidence would severely disadvantage the defence, the judge would be expected to give them a copy. Therefore, in extreme cases, we can rely on the judge to balance the complainant's right to privacy with the defence's right to a fair trial. 


\section{Word count}

The text of this paper (excluding table of contents, footnotes, and bibliography) comprises approximately 7,468 words.

\section{Bibliography}

\section{Legislation:}

Criminal Disclosure Act 2008.

Evidence Act 2006.

Evidence Regulations 2007.

New Zealand Bill of Rights Act 1990.

Victims Rights Act 2002.

New Zealand Case Law:

Attorney-General v Otahuhu District Court \& Anor [2001] 1 NZLR 737.

Gisborne Herald Co Ltd v Solicitor-General [1995] 3 NZLR 563, 573.

$M v R[2011]$ NZCA 303.

Police v Mauseuga DC Porirua CRI-2012-091-1439 13 August 2012.

$R v B$ [1995] 2 NZLR 172.

$R v$ Heemi CA143/98, 5 October 1998.

R v Henning, DC Wellington CRI-2010-078-1159, 5 July 2011.

$R v$ Hines (1997) 3 NZLR 529, 548 (CA).

$R v$ Hinorangi DC Wellington CRI-2009-085-00788.

$R v O$ [2012] NZCA 475.

$R v$ Shone [2008] NZCA 313.

\section{United Kingdom Case Law:}

Fitt v UK (2000) 30 EHRR 480.

\section{Canadian Case Law:}


$R v$ O’Connor [1995] 4 S.C.R. 411.

\section{Australian Case Law:}

Hinch v Attorney-General for the State of Victoria (1987) 164 CLR 15, 58 (HCA).

\section{Journals Articles:}

Don Mathias “The Accused’s Right to a Fair Trial: Absolute or Limitable?” (2005) 2 NZLR 217

Elisa Toma “The Principle of Equality of Arms- Part of the Right to a Fair Trial” (2011) 1(3) Romania Law Review 1.

Elisabeth McDonald "Sexual Violence on Trial: Assisting Women Complainants in the Courtroom" (2005) 19(2) Women’s Studies Journal, 2005, 107.

Emma Davies and Kirsten Hanna “Pre-recording testimony in New Zealand: Lawyers' and victims advisors' experience in nine cases” (2013) 46 Australian \& New Zealand Journal of Criminology 289.

Emma Davies and others “Prerecording children’s entire testimony” (2011) New Zealand Law Journal 335.

Frank Carrington “Victims’ Rights Litigation: A Wave of the Future?” (1977) 11(3) University of Richmond Law Review 447.

Jan Jordan "Worlds Apart? Women, Rape and the Police Reporting Process” (2001) 41(4) Br J Criminol 679.

Jennifer Temkin “Digging the Dirt: Disclosure of Records in Sexual Assault Cases” (2002) 61(1) The Cambridge Law Journal 126.

Lynne Henderson “The Wrongs of Victim’s Rights” (1985) 37(4) Standford Law Review 937.

Mark Kebbell, Becky Milne, and Graham Wagstaff "The cognitive interview: a survey of its forensic effectiveness” (1999) 5 Psychology, Crime and Law 101.

Mark Kebbell and Becky Milne "Police officers' perception of eyewitness performance in forensic investigation” (1998) 138(3) Journal of Social Psychology 323.

Nina Westera, Mark Kebbell "Promoting pre-recorded complainant evidence in rape trials: Psychological and practise perspectives” (2011) 35(6) Criminal Law Journal 376.

Nina Westera, Becky Milne, Mark Kebbell "It is Better, but Does it Look Better? Prosecutor Perceptions of Using Rape Complainant Investigative Interviews as Evidence” (2012) Routledge.

Nina Westera, Mark Kebbell and Becky Milne "Losing two thirds of the story: A comparison of the video recorded police interview and live evidence of rape complainants” (2013) 4 Criminal Law Review 290. 
Ronald Fisher and others "Field test of the cognitive interview: enhancing the recollection of actual victims and witnesses of crime” (1989) 74 Journal of Applied Psychology 722.

Yvette Tinsley and Elisabeth McDonald "Use of Alternative Ways of Giving Evidence by Vulnerable Witnesses: Current Proposals, Issues and Challenges” (2011) 42 VUWLR 705.

\section{Papers and Reports:}

Anne Ryan "Adult interviewing- current and proposed police practise” (paper presented by Anne Ryan, Detective Senior Sergeant, Practice Leader: Investigative Interviewing- RNZPC).

Aphra Green Regulatory Impact Statement: Harmful Digital Communications (Ministry of Justice, 2013).

Justice and Electoral Committee Evidence Bill (256-2) (24 October 2006).

Kirsten Hanna and others Child Witnesses in the New Zealand Criminal Courts: A Review of Practise and Implications for Policy (Institute of Public Policy, AUT University, 2010).

Law Commission The Evidence of Children and Other Vulnerable Witnesses: A Discussion Paper (Law Commission, Preliminary Paper 26, October 1996).

Law Commission Evidence Volume 1: Reform of the Law (NZLC R55, 1999).

Mary Schollum “Invetigative interviewing: The Literature” (2005) New Zealand Police, Wellington.

Ministry of Justice Alternative pre-trial and trial processes for child witnesses in New Zealand's criminal justice system: Issues Paper (Ministry of Justice, 2010).

Ministry of Justice The Guidelines on the New Zealand Bill of Rights Act 1990: A Guide to the Rights and Freedoms in the Bill of Rights Act for the Public Sector (Ministry of Justice, November 2004).

Ministry of Women's Affairs Restoring Soul: Effective Intervention for Adult Victim/Survivors of Sexual Violence (Ministry of Women's Affairs, October 2009).

Submission from the New Zealand Law Society to the Claire Norris of the Ministry of Justice to comment on the Ministry of Justice's Issue Paper on Alternative pre-trial and trial processes for the child witness in New Zealand's criminal justice system (Issues Paper) (25 February 2011).

Triggs and others Responding to sexual violence: Attrition in the New Zealand criminal justice system (Ministry of Women’s Affairs, September 2009).

Venezia King and Jan Jordan Responding to Sexual Violence: Pathways to Recovery (Ministry of Women's Affairs, Wellington, 2009).

\section{Essays in books:}

Barbara Krahe and Jennifer Temkin Sexual Assault and the Justice Gap: A Question of Attitude (Hart Publishing, Oxford, 2008). 
Yvette Tinsley and Elisabeth McDonald "Evidence Issues" in Yvette Tinsley and Elisabeth McDonald (eds) From "Real Rape" to Real Justice: Prosecuting Rape in New Zealand (Victoria University Press, Wellington, 2011) 123.

\section{Books:}

Paul Rishworth and others The New Zealand Bill of Rights (Oxford University Press, Auckland, 2003).

Richard Mahoney and others The Evidence Act 2006: Act and Analysis (2nd ed, Brookers, Wellington, 2010).

\section{Government Publications:}

Baroness Stern The Stern Review: A Report by Baroness Vivien Stern CBE of an Independent Review into how Rape Complainants are handled by Public Authorities in England and Wales (Government Equalities Office, 2010).

Cabinet Domestic Policy Committee "Child Witnesses in the Criminal Courts: Proposed Reforms" (6 July 2011) DOM 10/1.

Cabinet Social Policy Committee “Amendments to the Evidence Act 2006” (12 November 2013).

Simon Power A Focus on Victims of Crime: A Review of Victims' Rights (Ministry of Justice, December 2009).

\section{Internet Sources:}

Crown Law "Victims of Crime- Guidance for Prosecutors” (5 March 2012) Crown Law $<$ http://www.crownlaw.govt.nz/uploads/victims_of_crime.pdf>.

Human Rights Review “Article 6: the Right to a Fair Trial” (2012)

$<$ http://www.equalityhumanrights.com/uploaded_files/humanrights/hrr_article_6.pdf>.

Marie Dyhrberg "Barriers to defence access to Witnesses for the Prosecution- An Antipodean Perspective” (October 2007) Marie Dyhrberg: Papers \& Articles $<$ http://www.mariedyhrberg.co.nz/papers-and-articles/>.

Ministry of Justice “A Guide to the Victims Charter” Ministry of Justice $<$ http://www.justice.govt.nz/publications/global-publications/v/victims-charter-booklet-a-guide-tothe-victims-charter/documents/23510-Victims-Booklet-13-0.pdf>

Ministry of Women’s Affairs “Dialogue on sexual violence” (1 May 2014)

$<$ http://mwa.govt.nz/news/dialogue-sexual-violence>.

Office of the High Commissioner for Human Rights "International Covenant on Civil and Political Rights” (1996) United Nations Human Rights $<$ http://www.ohchr.org/en/professionalinterest/pages/ccpr.aspx>.

\section{Conventions:}


Council of Europe Convention for the Protection of Human Rights and Fundamental Freedoms as amended by Protocols No. 11 and No. 144 November 1950, ETS 5.

\section{Interviews:}

Interview with Anne Ryan, Investigative Interviewing and Project Manager for the New Zealand Police (the author, Wellington, 7 May 2014). 